\title{
Unmet Needs for Legal Services in Australia: Ten Commandments for Australian Law Schools*
}

\author{
The Hon Michael Kirby AC CMG
}

\begin{abstract}
After outlining some strengths and failings of the law in Australia in meeting individual and community needs for legal services, the author explains why the recent over-supply of law graduates is unlikely to cure the shortfall in services. He proposes ten 'commandments' for Australian law schools, namely to:

1. Assure a more diverse intake;

2. Attend to vulnerable students, so that they survive their studies;

3. Address particular subjects of poverty law;

4. Encourage engagement by future lawyers with civil society;

5. Promote involvement with all forms of legal aid;

6. Acknowledge the importance of the law on costs;

7. Enhance access to law through new technology;

8. Establish miscarriage of justice and innocence clinics;

9. Undertake reliable empirical research and law reform projects; and

10. Consider basic lessons to be derived from foreign legal systems.
\end{abstract}

Legal academics, he concludes, have a special duty to critique their discipline and to provide a sense of engagement among lawyers (starting with law students) with the values of the laws they help to implement.

\section{Starting With Realities}

\section{A In the Beginning: Our Blessings}

When lawyers meet they sometimes speak in praise of legal institutions and the legal profession. Even occasionally of the judges and of legal education I have done this myself. There is much of which we can be proud: our independent courts that uphold the rule of law and constitutionalism. ${ }^{1}$ The substantially uncorrupted judiciary and public service. The independent and vigilant legal profession. Our long established electoral democracy,

\footnotetext{
* $\quad$ Delivered as the Leo Cussen Justice Lecture 2015 to the Australian Law Teachers' Association Conference at La Trobe University, Melbourne on 17 July 2015. The author acknowledges the research assistance of Mr Callum Dawlings, tutor in law of La Trobe University School of Law, who is not, however, responsible for the conclusions.

1 Australian Communist Party v Commonwealth (1951) 83 CLR 1, 193; see also Plaintiff S157/2002 v Commonwealth [2003] HCA 2; 211 CLR 476, 513 [103].
} 
with its essential features expressed in the Constitution. ${ }^{2}$ Our excellent universities and institutions of learning, now boasting 36 law schools. Our law reform bodies, including the Australian Law Reform Commission (ALRC) which in 2015 celebrates its 40th anniversary. And many other achievements.

I am not one to adopt a harsh view of Australia's system of law and justice. The way ahead, as in the times past, is likely to be the way of reform; not revolution. The challenge is to find a harmonious mean between stiff and grand complacency about the faults of the law, on the one hand, and a condescending demand to tear up the present system and start again, on the other.

\section{B The Great Stain: Indigenous Disempowerment}

It has become usual to commence legal conferences in Australia, with an acknowledgement of the indigenous people, long neglected or misused by the law. ${ }^{3}$ This is to be welcomed. So is the bipartisan proposal of Australian's political leaders to insert in the Constitution a new Preamble, acknowledging the indigenous people and their special place in the nation. ${ }^{4}$ Symbols are important. However, if any such Preamble were voted on for the Constitution, excluding any justiciable operation, it is doubtful that the perils of debating it, and the benefits of adopting it, would outweigh the danger of another opportunity lost. Especially since the 1967 amendment to the Constitution, ${ }^{5}$ many legal changes have been introduced by legislatures and the courts. Yet every informed Australian knows the severe social problems confronting our indigenous people: particularly in health care, housing, education and justice.

In any attempt to identify the unmet needs for legal services in Australia, and to address the failings of the Australian legal system, it is essential, to give priority to the grave situation that faces Australia's indigenous people when most of them come into contact with the law. I refer to the extremely high rates of imprisonment that involve indigenous Australians. This is not a new problem. Yet it appears to be getting worse; not better.

The general rates of imprisonment in Australia have reached historic highs in many parts of the nation. A recent analysis of full-time imprisonment undertaken by the Judicial Commission of New South Wales and published in 2015, recorded: ${ }^{6}$

$2 \quad$ Roach v Electoral Commissioner [2007] HCA 43; 233 CLR 162.

3 As explained in Mabo $v$ Queensland (No 2) (1992) 175 CLR 1.

4 The earlier 1967 referendum repealed s 127 of the Constitution and deleted the exclusion of 'the aboriginal race' previously appearing in s 51(xxvi) of the Constitution.

$5 \quad$ Constitution Alteration (Aboriginals) Act 1967 (Cth).

6 Judicial Commission of New South Wales, Sentencing in NSW: A cross-jurisdictional comparison of full-time imprisonment, Research Monograph No 39 (2015) 43 [5.1] (footnote omitted). 
In 2014, Australia's prisoner numbers reached a 10 year high. As at 30 June 2014, there were 33,791 prisoners, (sentenced and unsentenced) in Australian prisons. This represents an increase of 10\% from 2013 and equates to $0.19 \%$ of Australia's adult population in Australia's corrective services custody. Of [these], 25,513 were sentenced prisoners and 8,210 (24.3\% of the total prison population) were unsentenced, representing an increase of $11 \%$ from 30 June 2014 . The most common offences for male prisoners (who made up $92 \%$ of the prison population) were acts intended to cause injury, unlawful entry with intent, and robbery, extortion and related offences.

However, if this bleak picture of the general population were insufficiently discouraging, a closer examination of indigenous incarceration suggests a major disconnect between the criminal justice system, Australian police and our indigenous population: ${ }^{7}$

Indigenous offenders are over-represented in the Australian prison system. The [Australian Bureau of Statistics] reported that, as at 30 June 2014, there were 9,264 prisoners who identified as Aboriginal or Torres Strait Islander. This accounted for just over a quarter (27.4\%) of the total prison population and represented a 10\% increase (834 prisoners) from 30 June 2013 to 30 June 2014. ... This was the highest number of Aboriginal and Torres Strait Islanders recorded in Australian prisons since 2004. The proportion of Aboriginal and Torres Strait Islander offenders in NSW prisons was $23.6 \%$. The Northern Territory had the highest proportion of Aboriginal and Torres Strait Islander prisoners (85.6\%), while Victoria had the lowest $(7.8 \%)$. The adjusted imprisonment rate for indigenous prisoners in Australia was 1,857.2 per 100,000 adult Aboriginal and Torres Strait Islander population. This is just under 13 times higher than nonindigenous prisoners who had an age standardised imprisonment rate of 144 per 100,000 adult non-indigenous population. On 30 June 2014, the median age of Aboriginal and Torres Strait Islander prisoners was 31.0 years, which is 4.3 years lower than the median age of non-indigenous offenders (35.3 years).

Under an established principle of the common law (reflected now in the provisions of Australian sentencing statutes ${ }^{8}$ ) imprisonment is expressed to be a sentence of last resort. Yet as a cohort of the Australian population, the level of imprisonment of indigenes is even higher, on a per capita basis, than the extremely high general rates of imprisonment in the United States of America and China. This is not a statistic of which Australians can be proud. Least of all lawyers who have special opportunities, and responsibilities, when it comes to criminal justice.

$7 \quad$ Ibid, 43 [5.1.1] (footnote omitted); New South Wales Bureau of Crime Statistics and Research, 'New South Wales Custody Statistics: Quarterly Update' (Report, New South Wales Bureau of Crime Statistics and Research, June 2015), revealed that the State's adult prison population grew by 12.2 per cent in the 2014 financial year - with the largest growth amongst remand and indigenous prisoners.

8 See, for example, Crimes (Sentencing Procedure) Act 1999 (NSW) s 5(1) ('A court must not sentence an offender to imprisonment unless it is satisfied, having considered all possible alternatives, that no penalty other than imprisonment is appropriate'). 
Because, as a general rule, legal aid is available to those who are at risk of a sentence of imprisonment, many or most of those imprisoned may have been legally represented. If so, it has had little beneficial effect. No apparent effect in lowering the world-beating statistic. The situation of indigenous incarceration is a source of shame to Australians generally and lawyers in particular. It probably has its roots in the long term economic deprivations of indigenous communities. In colonial times, Aboriginals were regarded as uncivilised nomads, with no interest in land or other property needing to be protected by the law. In the end, that judge-made postulate was corrected by judges in the $M a b o^{9}$ and $W i k^{10}$ decisions of the High Court of Australia. It was not earlier corrected by the democratic legislatures of the country, although, after 1856 this could have been done by the colonies or States and after 1967 it might have been done by federal legislation to address a specifically racial disadvantage of Aboriginal Australia. ${ }^{11}$ Yet it was not.

\section{The New Stain: Business or Profession?}

If this is the major problem of the Australian legal system as it operates in the case of indigenous citizens, there are different, but equally acute, challenges today facing other Australians, including even moderately prosperous Australians. In the lifetime of people like myself the law (and specifically the courts) have moved out of the reach of even middle class citizens. If Australians ever engage with courts, judges and lawyers, they enjoy the fine qualities of independence and impartiality already mentioned. However, very few other than corporate or governmental litigants, can really afford the costs, risks and uncertainties of litigation. Generally, it is just too expensive and chancy.

I recently had this reality brought to my notice. After nearly 40 years, I sold my home in Sydney to move to an apartment. The home was in the eastern suburbs. The land on which it was built enjoyed the benefit of an easement and a hundred year lease of a garage space: a valuable asset in that vicinity. I requested my neighbours, as successors to the original lessor, to execute a deed agreeing to the assignment of the lease from me to my purchaser. They raised various objections, coming down eventually to one that claimed exemption because they objected not to the purchaser or his immediate family but to the reported doings of some of his suggested relatives overseas.

The neighbours consulted successively three firms of lawyers, all within the space of two months. Two of them were top tier law firms. In the end, the neighbours agreed to execute the assignment but on the basis that I would pay their legal costs. This meant the reasonable legal costs of their receiving advice. I agreed. The account eventually presented by them was, in aggregate, over $\$ 36,000$. It is now the subject of an independent

$9 \quad$ Mabo v Queensland (No 2) (1992) 175 CLR 1.

10 Wik Peoples $v$ Queensland (1996) 187 CLR 1.

11 Constitution s 51 (xxvi). 
costs assessment. The dispute threatened to frustrate the sale of the property and also the purchase of my new apartment, for which expensive bridging finance had to be procured. It involved no actual proceedings before a court or tribunal. One has only to imagine what litigation costs might have been, had they eventuated.

At the outset of my life in law, in the 1950s, the costs of advice in such a minor dispute between neighbours would have been extremely modest, probably no more than a hundred guineas. This recent personal experience brought home to me the huge inflation in legal costs that have accompanied the migration of the Australian legal profession into high rise city offices with water views, international partnerships and a shift to a business model in place of a professional model. Someone has to pay the partner salaries and rents in the top tier firms. That someone is ultimately the client. These introductory reflections pose the question whether, in Australia, the law is in danger of losing its link to justice. And does anyone care?

\section{Oversupply OF LaWyers?}

The proliferation of law schools in Australia, that has accompanied the emergence of the foregoing challenges, has resulted in concerns about an 'oversupply' of law graduates for whom the traditional market in legal services cannot provide employment. ${ }^{12}$ This development parallels similar changes in other countries, notably the United States of America. In that country, for the first time in many years, the aggregate enrolments in law schools have lately dropped. Academic recruitment has fallen. Law school closures have even been predicted or reported. ${ }^{13}$

Of course, not every law school entrant now plans to follow the path that was so common in my generation. A law degree today affords openings in a much wider range of occupations than the traditional trajectory of articled clerk, solicitor, barrister, senior counsel and judge. In Australia, positions have opened up to in-house and corporate counsel; work in legal publishing; administrative positions in the public service; work in numerous tribunals, trade unions, civil society organisations, political posts and universities. The growth of international trade and of transnational corporations has also presented many new opportunities. So have off-shore legal appointments and overseas recruitments of experts in foreign law. These changes have led to suggestions in some quarters of the need to institute supplementary Bar examinations for those who intend to take the traditional path to become professional legal advisers or advocates on behalf of clients. ${ }^{14}$

12 Cf Chris Merritt, 'Call for Cap on Lawyers to Ease Strain', Australian, 4 April 2014, 22 reporting Warren CJ's remarks that Australia's law schools produced 12,000 graduates each year while the US, with ten times Australia's population, produces 45,000 law graduates; Elizabeth Lesly Stevens, 'The case against law schools', Washington Post Magazine, 4 November 2012, 40.

13 DC Weiss, 'About Half of Law Schools Surveyed Have Cut First-year Enrolment'. American Bar Association, 19 November 2012; Jennifer Smith, 'Law-School Professors face less job security', Wall Street Journal, 12 August 2013, B1.

14 The suggestion was made by Warren CJ, in the address reported, Merritt, above, $\mathrm{n} 12$. 
The optimistic might suggest that the increased enrolments in law schools will have the potential to afford a market solution to the shortage of lawyers, willing and able to fill the unmet need for legal services. In the ordinary operation of economic forces, can it be expected that an oversupply of legally trained and qualified personnel will find work by identifying and serving clients who cannot currently afford the costs of lawyers in the CBD of capital cities?

To some extent, this hope looks unrealistic. At a time of diminishing public funds for legal aid, the notion that an aged pensioner will ordinarily have sufficient disposable income to pay for the time-intensive advice of a trained lawyer, seems unrealistic. To obtain a law degree and professional qualifications, the graduate will have devoted at least three, and possibly five or more, years to undergraduate or postgraduate education. This will usually have been undertaken in times that otherwise could have been devoted to remunerative activities. It will give rise to reasonable expectations of a financial reward reflecting the time and costs expended in securing the qualifications.

Realistically, these considerations will therefore usually give rise to an expectation of a minimum sum that might be charged for the time- intensive task of consultation, research and advice by a professional lawyer: legally liable as such for the accuracy and appropriateness of the advice given. Accordingly, the expectation that large numbers of unemployed law graduates will flock to offer their services to those who presently cannot afford legal advice appears unrealistic. Market forces may reduce the expectations of some young law graduates, and the fees they may expect, or be willing, to charge. However, given overheads, licence and registration fees, insurance and office costs, it seems more likely that underemployed lawyers will look elsewhere for employment opportunities, probably outside the practice of law.

If this conclusion is correct, it is necessary to formulate a number of strategies that modern Australian lawyers and law teachers could undertake, beyond reliance on market forces, to help meet the unmet needs for legal services in the Australian community. To identify some of the steps that need to be taken, I propose ten new commandments to be observed by Australian law schools. These will suggest ten strategies that a contemporary law school might take to enhance the capacity and willingness of their graduates to fulfil the unmet needs for legal services in ways that will prove more imaginative and successful than the efforts of their predecessors, including those of my generation.

\section{Ten Commandments for LaW Schools}

\section{A Assure a More Diverse Intake}

Some lawyers are unconcerned about the unmet need for legal services. They may contend that it was ever thus. They may explain that it is an inescapable consequence of the time-intensive nature of individual 
lawyering. They may point to overheads and market forces. They may state, accurately, that plumbers and hairdressers rarely face demands to perform pro bono services.

However, law is not simply another occupation. It is concerned with governance and the rules by which people live together in society. Inability to secure effective access to the law can sometimes make our claims about the rule of law sound hollow. The beginning of a response to this problem is a realisation that it is a problem. Such a realisation is unlikely to come about if the legal profession, and its leadership, derive overwhelmingly from economically and socially privileged backgrounds. Yet, that appears to be the present situation.

A partial corrective to the generally privileged composition of graduates in law followed the Second World War. The Chifley Government implemented special assistance to war veterans to encourage them to enter universities. It also proposed a Commonwealth Scholarships Scheme to open up university education generally to students of lower parental means. The Menzies Government converted the Chifley Government idea of Commonwealth Scholarships into reality. It was one of that government's greatest achievements. Many students, myself included, who could not otherwise have afforded university education, entered law school and flourished by virtue of these scholarships. ${ }^{15}$ The influx of this post war cohort eventually led to research into the background of the new students. ${ }^{16}$

In Australia, this research was first undertaken on the socio-economic backgrounds of the new class of university students in medicine, engineering and teaching, as well as law. ${ }^{17}$ In England, Professor David Barker, soon to move to Australia, undertook research in that country on the specific law intake at the London Polytechnic (later the University of Westminster). These initiatives inspired Professor John Goldring (subsequently inaugural Dean at the University of Wollongong School of Law) to investigate the educational and attitudinal backgrounds of Australian law students. Goldring was interested in the conclusion of his predecessors that 'law students were the most politically conservative... groups tested, indicating [in 1965] that $50 \%$ of them would vote Liberal, and $33 \%$ Labor. (For student teachers the proportions were reversed) ${ }^{6}{ }^{18}$ Goldring had been taught at the Sydney Law School by Professor Julius

15 Michael Kirby, 'The Graduating Class of Sydney Law School 1962: Talented, Lucky, Unquestioning' (2012) 36(2) Australian Bar Review 189.

16 Michael Kirby, 'JL Goldring, Legal Education and A Most Unusual Occupation' (2014) 38(3) Australian Bar Review 226.

17 Don Anderson and John Western, Social Profiles of Students in Four Professions (Australian Council for Educational Research, 1970). See also Don Anderson and John Western, 'Notes on a Study of Professional Socialisation' (1967) 3 Australian and New Zealand Journal of Sociology 67; Don Anderson and John Western, 'Social Profiles of Students in Four Professions' (1970) 3 Quarterly Review of Australian Education 1.

18 Summarised in Julian Disney et al (eds), Lawyers (Lawbook Company, 1977), $136,140-141$. 
Stone. Stone challenged the objective thesis of law propounded by Chief Justice Sir Owen Dixon ${ }^{19}$ that then prevailed. Stone taught that judges and lawyers had choices to make in resolving many disputed issues of law and legal policy. ${ }^{20}$ Accordingly, those admitted to law school who went on to become lawyers were likely to reflect their antecedent attitudes and values. Values in. Values out. As himself a product of public (State) schools, Goldring was particularly curious to discover the educational profile of the nation's law students.

In his survey of law students, conducted in 1976, Goldring found that 20 per cent had fathers whose incomes were equal to, or less than, the average wage (then $\$ 9000)$. A greater number had fathers whose incomes were equal to, or above, $\$ 19,000$ - a high salary in those days. He found that, in 1976, 42 per cent of law students had a relative or family friend who was a solicitor; 24 per cent a barrister, and 15 per cent a judge. ${ }^{21}$ There was no way in 1976 that 15 per cent of the general Australian population could have boasted a family member or friend who was a judge. The figure would have been fewer than 1 per cent. They would not have included my family.

Goldring repeated his investigation in 1986. He found a sharp increase in the proportion of women entering the law course; significant differences between different law schools in the intake of older students; and a persistence of the patterns previously revealed concerning student educational backgrounds. Thus, in the 1986 survey, although 70 per cent of Australian students generally were then educated in public schools, Goldring found that only 41 per cent of those entering law schools had been educated there. The majority had been educated in private schools: 32 per cent in 'independent' schools; and 23 per cent in Roman Catholic schools. The biggest disparities in this regard were found in the oldest law schools (the Universities of Melbourne and Sydney). ${ }^{22}$

Goldring, remembering Stone, saw at once the significance of these results. He concluded that 'Law students in full-time courses remain an affluent and privileged group'. ${ }^{23}$ Goldring's later judicial appointment and early death robbed us of a continuation of his profile surveys of later law students. The surveys should be revived. Anecdotal evidence suggests that not much has changed.

During most of my service on the High Court of Australia, I was the only Justice whose entire education had been in public schools. I dislike the appellation 'great dissenter'. But dissent in judicial decision-making

19 Speech by Sir Owen Dixon on assuming the office of Chief Justice reported Commonwealth Law Reports, Michael Kirby, 'The Judges' (Speech delivered at Boyer Lectures, ABC, 1983), 37.

20 Julius Stone as explained in Leonie Star, Julius Stone, an Intellectual Biography (Oxford University Press, 1992); see Kirby, above n 16.

21 Disney et al, above n 18, 141.

22 Kirby, above $\mathrm{n} 16$.

23 John Goldring, 'Admission to Law Courses in Australia' (1977) 20 Vestes 61 and later John Goldring, 'Admissions Policy' in Law Council of Australia Foundation, Legal Education in Australia, vol 1 (Melbourne, 1978), 47. 
can be affected by background and values. These are the judicial 'can't helps', as Oliver Wendell Holmes Jr describes them. I am not hostile to private or religious schools. My selective school education in New South Wales, although in public schools, was in some ways privileged. However, the values were secular and democratic and the parental means of fellow students were not generally privileged. Our values were affected by our personal and school environments.

What have Australian law schools done to make the admission of students deriving from deprived and disadvantaged backgrounds easier? The answer is, not much. In fact, in the past decade, a number of steps have been taken that actually make the study of law for such students even more difficult.

Thus, the growing shift from undergraduate (LLB) degrees in Law to postgraduate (JD) degrees is doubly adverse. It introduces an obligatory longer period of university study, with consequential costs of investment in tuition and support. Moreover, it shifts many students from access to the Commonwealth HECS Scheme, available to undergraduates, into a full fee paying costs structure. In financial terms, it increases the immediate aggregate cost of securing legal qualifications from about $\$ 20,000$ to $\$ 100,000$. It also reduces the effective governmental subsidisation of repayments. Australia's full cost law degrees are now even more expensive than those of top universities in the United Kingdom and the United States. Comparatively speaking, in terms of costs, law is a cheap course for universities to offer. Putting it bluntly, universities can regard them as attractive money-earners.

It may not only be the practising legal profession that has lost its way in terms of professionalism. Some cynics suggest that the shift in Australia to JD course has been motivated, in part, by financial not educational considerations. Some law students (myself included) undertook the LLB course in combination with another undergraduate (liberal Arts) degree. However, this was done by choice and depended on capacity to afford the choice made. The JD course is not a true doctorate. Graduates cannot title themselves 'doctor'. Substantively, it is an undergraduate course but by another name. It is unlikely to have done anything to promote a change in the privileged profile of the intake in law courses in Australia. To the contrary, it seems likely to have deterred some entrants of limited means. It also adds to pressure to miniaturise the law course, out of recognition of the cost of undertaking it. Some law schools succumb to this pressure by discarding compulsory, or any, tuition in subjects previously thought essential such as the study of jurisprudence (legal theory); legal history; and engagement in community legal service.

Nevertheless, some universities have taken the objective of entrant diversity semi-seriously. UNSW Law has stepped up efforts to attract indigenous students. It has also introduced scholarships and school visits to outlying suburbs of its city to encourage students in non-selective public schools to consider law as an available vocation. Legal studies classes in high schools provide a potential opportunity to promote this objective. 
Other law schools (such as University of Central Queensland) have introduced a law degree taught wholly online. ${ }^{24}$ Charles Darwin University in the Northern Territory of Australia offers a law course promoted offshore and provided online. Such initiatives have been criticised in some traditional quarters as depriving students of the beneficial features of university life, beyond the classroom. However, a police constable in the outback of a decentralised State such as Queensland might have no other prospect of undertaking a law course. Likewise, an Aboriginal community worker in Western Australia or the Northern Territory or an expatriate Australian working in the Gulf may find such courses essential, if they are to fulfil their legal aspirations.

All Australian law schools should ask themselves what they are doing to ensure that the profile of their students aligns more closely with the profile of the community that law graduates will need to serve on graduation. Business as usual is an endorsement of privilege.

\section{B Help the Vulnerable to Graduate}

In addition to addressing the intake of new law students, law schools must be aware of the challenge of survival during the course.

Common experience, and also recent research in Australia, have demonstrated the importance of depression, low self-esteem, disillusionment, bullying and suicidal thoughts for students generally and law students in particular. ${ }^{25}$ It is surprising to some that this is a greater challenge for law students than for those in other disciplines (such as dentistry and medicine), which one might think presented greater risks because of the intensity and personal nature of the work. The University of Melbourne and QUT law schools have taken a lead on these topics. Most law schools are now addressing them.

The Tristan Jepson Foundation promotes awareness and research on depression amongst law students. Recently, I helped launch the Daniel Solomons Scholarship. ${ }^{26}$ It remembers the life of an excellent student from UNSW Law who took his own life whilst suffering from clinical depression. Tragically, these problems are not rare. Certainly, they need to be addressed by more than inclusion in a guidance lecture in the first year, during orientation week. In fact, the evidence suggests that many law students suffer serious depression in the middle of their university courses, when they realise that the ideals that took them into law in the first place seem very distant from their daily experience. Getting

24 Michael Kirby, 'Online Legal Education in Australia: the New CQU Law Degree' (2011) 34(3) Australian Bar Review 237.

25 Michael Kirby, 'John F Kearney, Legal Education and Life Opportunities' (2013) 25 Bond Law Review 2, 7-16.

26 Michael Kirby, 'Lawyers' Suicide: The Influence of Legal Studies And Practice, Stress, Clinical Depression And Sexuality' (2015) 38(4) University of New South Wales Law Journal 1438; cf Melissa Castan, Jeannie Paterson, Paul Richardson, Helen Watt and Maryanne Dever, 'Early Optimism? First-Year Law Students' Work Expectations and Aspirations' (2010) 20(1) Legal Education Review 1. 
aspirational students through a law course is as important as first attracting them to enter.

As with child abuse, there appears to be some evidence that bullying, which is a related but distinct challenge, starts early in life and is often practised by those who have themselves suffered from it. ${ }^{27}$ Bullying is found at every level of experience. Some judges are bullies. But some judges are also the subject of attempted bullying by litigants, advocates and colleagues. To some extent, the adversarial system in the law is built upon a methodology of conflict and contest. This has certain advantages in eliciting truth from contested facts and revealing logical and other flaws in propositions being advanced by opponents. But it can present a stomach-churning experience for those who may be more vulnerable.

Similarly, the inability to delegate some tasks in the law; the long hours of work; the relentless concentration that is needed on particularities; and the public character of many legal performances combine to impose a potential toll in stress and diminished self-confidence. Until recently, few law schools mentioned this subject in more than a perfunctory way. The argument of 'heat in the kitchen' was usually invoked to excuse the imposition of unreasonable demands. Because the culture is imbibed by, and evident in, most law schools, the response must begin there. The pedagogical and legal duty of care requires a strategy on the part of law teachers. By improving the environment at law school and establishing effective responses to stress and misbehaviour, law schools may contribute to improvement in the long term conduct of their graduates, wherever they may end up down the track.

There is particular evidence that young people in Australia who came from sexual minorities (LGBTIQ) have greater than average exposure to mental health problems when growing up and undertaking study, including in law schools. Research lately undertaken by the Western Sydney University and others ${ }^{28}$ showed that 16 per cent of young people, who identify as members of a sexual minority, had considered suicide and 33 per cent had harmed themselves. Many had done so in consequence of homophobic and transphobic harassment and violence which they had faced. The special challenge of 'coming out' during educational years presents the occasion, and opportunity, for very high levels of stress but also opportunities for effective institutional responses and support.

Technology as a source of information and a means to form friendships can be a venue for knowledge and reassurance; but also of bullying. The creation in law schools of 'Outlaw' and 'Ally' organisations is specially urgent because of the evidence of heightened stress during that course of study. One Australian law school was reported to have denied the

27 Michael Kirby, 'Judicial Stress and Judicial Bullying' (2013) 87 Australian Law Journal 516.

28 Kerry H Robinson, Peter Bansel, Nida Denson, Georgia Ovenden and Cristyn Davies, 'Growing Up Queer: Issues Facing Young Australians Who Are Gender Variant and Sexuality Diverse' (Research Discussion Paper, Young and Well Cooperative Research Centre, February 2014). 
opportunity for the formation of an LGBTIQ group, or meetings, on campus, allegedly on religious grounds. If this were true, it would obviously need to be reversed because of the special risks that the affected cohort faces. However, there would also be heightened risks amongst other particular groups: women, Muslims, Aboriginal and other students in need of special support. At the ANU, one senior academic (not himself from a sexual minority) placed a message of support and rainbow colours on his door to indicate his availability to discuss such student problems with any student wishing to do so. Sometimes, as I myself have found, it is useful if law academics from minorities, including sexual minorities, identify openly with the minority. This can help to dispel the feeling of isolation and unacceptability. Certainly, this topic needs to be addressed and responded to.

\section{Include the Teaching of Poverty Law}

When Professor Sackville, then at the Melbourne Law School, undertook his work for the Poverty Commission in the 1970s, he demonstrated the unremarkable fact that, legally speaking, poorer people are not simply rich people without money. They have their own distinctive engagements with the law. These do not exactly parallel the legal problems of the economically well-off. If at no level in a law course there is any exposure amongst law students to the areas of law that typically affect economically disadvantaged fellow citizens, it is unsurprising that there will be little or no knowledge, awareness or empathy about the legal problems of people living in various degrees of poverty.

Inevitably, perhaps, the law course will normally be designed in Australia around the 'Priestley 11' subjects, endorsed for instruction, eked out with selected optionals. Many optional courses will be addressed to financially rewarding areas of the law likely to arise in a commercial practice. This is the consequence of the re-emergence of vocationalism as a prime purpose of Australia's legal education. ${ }^{29}$ Especially so at a time of the suggested over-supply of qualified law graduates.

Having no family connection with the law in my upbringing, I found it difficult to obtain articles of clerkship. ${ }^{30}$ This was despite very good school grades. That is how I came to work initially in workers' compensation law. Actually, this was a subcategory of poverty law although I did not see it that way at the time. Its problems were those of ordinary working people, injured in the course of their employment or on employment journeys. As I discovered from my daily work, there was a huge body of law on the meaning of the legislation, litigated in the New South Wales Workers' Compensation Commission and appellate courts. It was technical, hard fought, often interesting and extremely important for the

$29 \quad$ Nickolas John James, 'Why has Vocationalism Propagated So Successfully Within Australian Law Schools?' (2004) 6 University of Notre Dame Australian Law Review 41, 57. 
clients concerned. ${ }^{31}$ The workers were supported by the State Trades and Labor Council. The lawyers engaged in these cases uniformly worked on the principle of 'no win, no pay'. Workers' compensation and injury law were never mentioned in my law course. Most of the time at law school was devoted to the subjects of property law, with jurisprudence, international law and constitutional law thrown in. The only subjects of law that concerned the lives of ordinary citizens were criminal law and family law (then called 'Divorce'), in which such people generally became embroiled involuntarily.

Because of the cost ratio of time required to the amount at stake, it is unlikely that many of the subjects of the law of concern to poorer citizens will ever secure much time in a law course. Yet today, in Australia (as in the United States and the United Kingdom earlier) community legal advice offices have been created to address at least some of the urgent unmet needs for legal services of such people.

When I was a law student, legal advice was sometimes provided (if at all in New South Wales) by Chamber Magistrates. These were Clerks of Petty Sessions, sitting in their chambers at the local courthouse, giving free legal advice to a parade of ordinary citizens of low economic means who had a problem but could not afford to have a lawyer advise them. It is the disappearance of that and other public facilities that has led to the increasing numbers of litigants in person who now attempt, at huge disadvantage to themselves, to present their cases before Australia's courts. They do so at every level of the court hierarchy, up to the High Court of Australia. Occasionally, they enjoy a significant victory. ${ }^{32}$

The medical, dental, veterinary and other helping professions are better organised to provide essential and urgent care for ordinary citizens in need of free advice. Starting at law school, the law is much less effective in this task. In fact, it has never been well-organised for this purpose. Some legal practitioners are unconcerned, except in an inert way.

One initiative that has been taken in recent times has been the creation, at the Alfred Hospital in Melbourne, of the HeLP clinic. This is a joint enterprise of the hospital itself, the legal firm of Maurice Blackburn, Lawyers, and Monash University. ${ }^{33}$ The object of establishing the facility was to respond to unmet legal needs presented by patients at the hospital. ${ }^{34}$ The particular aspects of needs addressed by the clinic were characteristically instances where an individual's problems had

31 The problems occasionally visited the High Court of Australia during my service: Zickar v HGH Plastic Industries Pty Ltd (1996) 187 CLR 310; Vetter v Lake Macquarie City Council [2001] HCA 12; 202 CLR 439.

32 See, for example, Gassy v The Queen [2008] HCA 18; 236 CLR 293.

33 Monash University established the Michael Kirby Centre for Public Health and Human Rights which helped initiate this project.

34 Christine Coumarelous, Deborah Marcourt, Julie People, Hugh M McDonald, Zhigang Wei, Reiny Irana and Stephanie Ramsay, 'Legal Needs in Australia - Australia-wide Survey' (Report, Law and Justice Foundation of New South Wales, August 2012) 2. 
both a medical and legal element. ${ }^{35}$ Social workers might try to help resolve the legal problem, particularly by making representations on behalf of the client to relevant government agencies. However, because of lack of expertise, the legal problem was frequently unperceived or unaddressed.

In the United Kingdom, community legal service partnerships arose to respond to similar solutions. In the United States of America, there are now 275 formally constituted medical/legal partnerships. They provide a range of services extending from 'legal advocacy to healthcare to helping to secure access to benefits and protections'. ${ }^{36}$ The Alfred Hospital, by inheritance, succeeded to the former Fairfield Hospital's special outreach to HIV/AIDS patients in the early years of that epidemic. Many patients suffering from HIV or AIDS presented with mixed medical and legal problems. This made The Alfred a natural venue at which to establish a multidisciplinary centre in Melbourne. Maurice Blackburn provided an experienced lawyer to help launch the centre. That firm had a long history of engagement with clients of lower economic means. The legal problems typically concerned workers' compensation, consumer protection, refugee claims, indigenous issues, domestic violence, employment disputes and disputes involving police or other government departments and agencies. Across the city of Melbourne, in West Heidelberg, Baker and Makenzie Lawyers, funded a cancer patients' clinic to supplement medical advice with any legal advice that the patients with cancer needed.

It sometimes happens, when cross disciplinary issues arise within particular legal firms, that links are perceived that allow the grouping of cases having common elements, appreciated because of the development of particular expertise. Thus, claims by people with disabilities may be grouped: a class action brought in relation to employment rights of large numbers of workers with intellectual disabilities treated in a similarly discriminatory way; claims for the neglected health rights of refugee applicants can be grouped; and local government issues may be organised into common litigation. ${ }^{37}$

Some Australian lawyers are unsympathetic (even hostile) towards group litigation. Though this - a combination of litigants, sharing common legal claims - may be the only effective way to bring ordinary people, affected by a common legal wrong, to a realistic chance of asserting their legal rights and obtaining redress. I witnessed this hostility in the professions' response to the early work of the Australian Law Reform

$35 \quad$ Pascoe Pleasence and Nigel J Blamer, 'Mental Health and the Experience of Social Problems Involving Rights: Findings from United Kingdom and New Zealand' (2009) 16 Psychiatry, Psychology and Law 123.

36 Christine Coumarelous, Pascoe Pleasence and Zhigang Wei, 'Law and Disorder, Illness, Disability and the Experience of Everyday Problems Involving the Law' (2013) Law and Justice Foundation of New South Wales, Justice Issues 24, 3.

37 Martha Minow, 'Foreword, Medico-Legal Partnerships Raise the Bar for Health and Justice' in Elizabeth Tobin Tyler (ed), Poverty Health and Law: Readings and Cases for Medical-legal Partnership (Carolina Academic Press, 2011) xv. 
Commission on class actions in Australia. ${ }^{38}$ Hostility was also sometimes evident in approaches taken in the courts to the legislation enacted to permit representative proceedings $;^{39}$ to a new approach to legal costs in environmental proceedings; ${ }^{40}$ and above all, to litigation funding, without which representative actions might never get off the ground. ${ }^{41}$ Some lawyers whose upbringing, education, social life, professional practice and personal connections have been exclusively with moneyed interests may be basically unwelcoming to efforts in the law to redress the unmet needs to pursue legal rights against such interests.

Those who truly believe in, and accept, the principle of equality before the law (and who seek to translate that belief into action) often face an uphill battle. ${ }^{42}$ Law teachers who accept the rhetoric of the rule of law will, at the least, endeavour to alert their students to the necessity of translating the law's fine words and theory into practical reality. These are matters that should be thoroughly addressed in every law course. They tend to expose dark corners of the law and deep flaws in its rules and procedures that need to be faced up to and reformed.

\section{Encourage Diversity and Civic Engagement}

Even where a law student's background and experience has been narrow and privileged, their eyes may be opened by engagement with civil society and with colleagues having different backgrounds and life experiences. An engagement with civil society might be especially beneficial because of the profile of most students in law schools, as revealed in the research of Goldring and others. The persistent patterns of social, economic and cultural backgrounds will (according to the evidence) also be reflected in the racial composition of many of Australia's law schools today.

Australia in the 1960s was, racially speaking, monochrome and relatively unquestioning about racial discrimination. ${ }^{43}$ Steps to repeal the legislation sustaining the White Australia policy were not initiated until 1966, under the Holt Government. ${ }^{44}$ The returns were completed by the Whitlam Government in 1974. Until then, it was difficult, even

38 Australian Law Reform Commission, Grouped Proceedings in the Federal Court (Report, No 46, 1988).

39 See, for example, Carnie v Esanda Finance Corporation Ltd (1995) 182 CLR 398; Wong v Silkfield Pty Ltd [1999] HCA 48; 199 CLR 255, 404.

$40 \quad$ Oshlack v Richmond River Council [1998] HCA 11; 193 CLR 72.

41 Campbells Cash \& Carry v Fostif Pty Ltd [2006] HCA 41; 229 CLR 386, 449 [138]. In Fostif, I acknowledged legitimate concerns about some aspects of representative procedures and litigation funding. See, Lee Aitken, 'Before the High Court: 'Litigation Lending' after Fostif: an Advance in Consumer Protection or a Licence to 'Bottomfeeders?' (2006) 28(1) Sydney Law Review 398, 404.

42 See also Michael Kirby, 'Deconstructing the Law's Hostility to Public Interest Litigation' (2011) 127 Law Quarterly Review 537.

43 Kirby, above $\mathrm{n} 15$.

44 After 1958, a non-racial immigration policy was gradually introduced into Australia. Cf Pacific Island Labourers Act 1901 (Cth); cf Migration Act 1958 (Cth). 
for Australian citizens who married a person of Asian or African ethnicity overseas, to bring their spouse back to Australia. There was a lot of racial prejudice. It was reinforced by a general lack of contact with 'alien' people of different ethnicity and culture..$^{45}$ Only when that contact began to increase, after the $1960 \mathrm{~s}$, did the hostility recede to the extent that it has.

This is why it is desirable for law schools to reflect the diversity that now exists in the Australian nation. Doing so is no more than an acknowledgement of the international condemnation of racism and a positive reflection upon Australia's geographic position in the world. It is also a prudent adjustment to the huge economic and other opportunities which our geographic location has presented to us, including in the law.

Although 9.6 per cent of Australia's population identify as being of Asian ethnicity or derivation, ${ }^{46}$ the penetration of the legal employment group by Asians remains relatively slow. Only 3.1 per cent of partners in Australian legal firms identify as Asian. Only 1.6 per cent of barristers and only 0.8 per cent of members of the judiciary do so. ${ }^{47}$ In large legal firms with more than 40 partners, the average appointment of Asian partners is only 3.2 per cent. In medium sized legal firms (10-40 partners) the average is but 2.7 per cent. In six large legal firms in Australia there are no Asian Australian partners at all. In 44 medium sized firms there are none. Amongst the 6160 barristers in Australia, fewer than 100 identify as Asian Australians. Progression within the legal profession is also disproportionately slow. Amongst senior counsel only seven so identify. ${ }^{48}$

Because of the way in which the judiciary is appointed in Australia, these figures contribute to a judiciary that does not reflect the prevailing and growing features of the contemporary Australian community. The beginning of the solution must be found in law school recruitments. Indeed, it needs to start in Australia's primary and secondary schools. This is important because of the special part that the law plays in governance and in the reflection of our community values. Law is not an ordinary occupation. Even allowing time for the law to catch up with big community changes, there appears to be something alien about the law, so far as young entrants from minority ethnic backgrounds are concerned. Is law too verbal; grounded in the English language? Does it, like the Australian Defence Force, appear to outsiders to be too English in its culture? Is its adversarial culture alien to those used to deference and consensus?

Law schools need to address these issues to ensure that the Australian lawyers of the future, at least in a general way, reflect the population

$45 \quad$ Frank Brennan and F Dominello, 'Race' in AR Blackshield, Michael Coper and George Williams (eds), The Oxford Companion to the High Court of Australia (Oxford University Press, 2001) 576 referring to O'Keefe $v$ Calwell (1949) 77 CLR 261; Koon Wing Lau v Calwell (1949) 80 CLR 533; Wong Man Onv Commonwealth (1952) 86 CLR 125.

46 Statistics from Diversity Council, Australia, 2014.

47 Ibid.

48 Asian Australian Lawyers' Association, The Australian Legal Profession Snapshot, 2014. 
patterns of the general community and its values. This is important, amongst other reasons, to reinforce community support for the essential values of the rule of law and uncorrupted officeholders. The Confucian ethic typically idealises the rule of 'powerful men of virtue'. To preserve the 'rule of law, not of men' it is essential to attract to engagement in the law not only Australians of Caucasian and Aboriginal ethnicity but also Australians of Asian, Arab, African, Pacific and Latin-American backgrounds.

To ensure that law students take steps outside their privileged family and familiar circles (where such is the case), it is desirable that they be encouraged to participate in community groups in civil society. In my youth, this was often achieved by participation in student activities, church groups, and (for law students at least) societies concerned with what we would now describe as human rights issues. The last included the Councils for Civil Liberties, the Australian Section of the International Commission of Jurists; Amnesty International and now Human Rights Watch.

To encourage the development of a values system that extends beyond vague and sometimes unrealistic rhetoric or motivation by private financial rewards and personal advancement, law schools should award credits for engagement by law students with civil society bodies that work for others, particularly the disadvantaged. There are now many such bodies, with which volunteer work is possible. These include bodies working with and for Aboriginals; HIV/AIDS legal centres; and bodies working with refugee applicants. In selecting my associates (law clerks), I always looked to the end of the biodata where applicants typically stated anything they had done for the disadvantaged. One (from Bond Law School) had volunteered for an Aboriginal community in the Northern Territory. Another (from Adelaide Law School) had taught English as a second language to refugee groups. Several had participated in student politics (as, earlier, Brennan CJ and I had done). For lawyers, anything that moderates the centrality of self, and aspirations defined in terms of the mega salaries of top tier law firms and of leading barristers, is prone to be beneficial. Law Schools in Australia must at least present the option of alternative pathways: in government service, in civil society organisations and in political parties. Only 2 per cent of the general Australian population are members of political parties - a much lower proportion than in any comparable society.

\section{E Encourage the Culture of Legal Aid}

Following the disappearance of the Chamber Magistrates of postwar Australia and the decline of public legal aid after the hopeful days of the 1970s, new and different strategies have been adopted to address unmet legal needs. They reflect the fact that the law does not (and arguably cannot) deliver justice to large sections of the community without private, voluntary supplementation. ${ }^{49}$

49 Murray Gleeson, 'National Access to Justice and Pro Bono Conference' (Paper presented at National Access to Justice and Pro Bono Conference 2006, 
Law students need to be alerted to this development and to a realisation of its importance for their long term careers in law. The public tap can be turned on; but it can also be turned off. Recent federal budgets in Australia have reduced government spending on public legal assistance. Thus, the 2014-2015 federal budget was pegged to direct $\$ 74.89$ million to indigenous legal assistance and $\$ 204.36$ million to other legal assistance services. In December 2013 a cut of $\$ 43.1$ million over four years in funds for legal assistance services was announced, together with a further $\$ 15$ million diverted from legal aid commissions.

These reductions led to State and Territory protests addressed to the Federal Attorney-General claiming that the 'down-stream' effects of such cuts would be harmful, even counter-productive, and costly in the long term. The Law Council of Australia, together with Aboriginal and Torres Strait Islander bodies and civil society organisations reminded the government of a report delivered by PriceWaterhouse Coopers in 2009. This had estimated that every dollar spent on legal aid returned $\$ 1.60-\$ 2.25$ in eventual real savings to the justice system. ${ }^{50}$ In consequence of these representations, the Commonwealth restored $\$ 25.1$ million to the legal aid budget.

However, the Productivity Commission's recommendation for an additional $\$ 200$ million for legal assistance has not been acted on. ${ }^{51}$ In the result, 'many Australians [who get] under the Henderson Poverty Line are still ineligible to qualify for legal aid'. ${ }^{52}$ This is the real world into which current law students are being ushered. The official response of the organised legal profession is improvisation and voluntary activity. However, these moves still leave many people, who objectively need skilled legal assistance, floundering - most of them through no fault of their own. This is an intensely frustrating, and sometimes clearly unjust, predicament where the untutored citizen must attempt to get by without a lawyer.

The legal profession has always performed what are now called pro bono services. Commentators argue the 'business case' to support such activity in contemporary Australia. Amongst other merits, it helps attract, and retain, talented young lawyers, keen to fulfil their ambition to contribute to a just, rule of law society. It leavens tedious but highly remunerative work with participation in intellectual and ethical challenges. During my

Melbourne, 11 August 2006), 4 cited in and applied by Chief Justice Warren, 'The Victorian Bar 10th Anniversary Pro Bono Presentation and Award Ceremony' (Melbourne, 18 May 2010), 2; see also Michael Kirby, 'Reception Honouring Pro Bono Lawyering' (2009) Victorian Bar News (Spring) 7; Stephen Parker, 'Why Lawyers Should do Pro Bono Work' (2001) 19 Law in Context 5.

50 Duncan McConnel, 'How Much Justice Can We Afford?' (2015) Law Institute Journal 91.

51 Ibid, referring to Australian Productivity Commission, 'Inquiry into Access to Justice Arrangements: Productivity Commission Inquiry Report’ (Report, 5 September 2014). Ibid, 91 . 
service on the High Court of Australia, many extremely important cases were brought to the Court on the initiative of pro bono departments in national legal firms. These included Mallard $v$ The Queen ${ }^{53}$ (miscarriage of justice) and Roach $v$ Electoral Commission ${ }^{54}$ (prisoners' right to vote).

Legal assistance schemes have also been organised by Australia's Bar Associations. They provide pro bono advocates for selected cases, and arrangements for duty lawyers to serve in busy courts. However, the entire pro bono system is an imperfect one. Many lawyers do not participate at all. Often proper preparation for a matter in court cannot be undertaken on the run. At least some large firms provide pro bono support under pressure from government with legal work out to tender on terms that take the provision of pro bono services into account as an incentive (or even a condition) for winning government retainers. ${ }^{55}$ Most people in need of legal assistance who cannot afford it, fall between the cracks under the current arrangements.

In a review of the system of legal aid now in place in Australia, Chief Justice Robert French recently quoted the comment of Professor Richard Abel on the paradoxes of pro bono: ${ }^{56}$

Pro bono provides high quality legal services to large numbers of clients who would otherwise go unrepresented, thereby helping to fulfil our legal system's promise of 'Equal Justice under Law'. But what a bizarre way to address a foundational element of liberal legalism. Could we imagine relying of volunteerism to perform other core government functions: police (the deputy sheriffs of the frontier are a distant memory), national security (privateers), foreign relations (honorary consuls), education (volunteer parents as the only teachers), or transportation (hitchhiking)?

I praise those lawyers who participate in pro bono. However, it is an imperfect solution to the functional needs of our legal system. It does not address the basic constitutional challenge of affording access to justice where that is essential. And it does not help solve the basic defects of the present justice system. It is important that those who are entering the law should be aware of these realities. Law students should be encouraged to be impatient, inventive and insistent and to suggest long term solutions. The very characteristics of excellence and independence of lawyers that marks the Australian legal system makes it expensive. It also makes it particularly forbidding for litigants who are not legally represented. But it provides a very clever cohort of people who can be encouraged to think creatively about the work they have chosen for their lives.

53 In the second appeal in Mallard he was represented by Mr M McCusker QC and Mr J Edelman, instructed by Clayton Utz, Perth, acting pro bono.

54 The summons in Roach was presented by R Merkel QC, FK Forsyth and KL Walker, instructed by Allens, Arthur Robinson acting pro bono.

55 Chief Justice Warren, above n 49, 2.

56 Chief Justice Robert French, 'Pro Bono Publico - Cui Bono?' (Speech delievered at the Law Summer School, Perth, 21 February 2014) 16, citing Richard Abel, 'The Paradoxes of Pro Bono' (2010) 78(5) Fordham Law Review 2443 (footnote omitted). 


\section{F The Special Importance of the Law of Costs}

I do not recall a single lecture in my law course addressed to legal costs. In those days, 'Procedure' was a compulsory subject. Theoretically, that subject might have included a lecture or two on the topic of costs. Ordinarily, in our legal system, costs follow the indemnity principle. Otherwise they are discretionary. Presumably, in my day, the subject of costs was thought unworthy of pedagogical treatment. Yet it does not take long in legal practice to learn how absolutely central to almost every undertaking in the law is the consideration of costs and of the likely amount and locus of the ultimate costs burden.

In the United States, the indemnity principle (the party that loses the case should ordinarily pay the basic legal costs of the winner so as to vindicate the winner's rights) was rejected at an early stage. Each party normally pays its own costs - which can be a huge burden if the parties are not equally well resourced. The indemnity principle was regarded as an unacceptable inhibition on the entitlement of citizens in the United States seek access to the courts. Even in the context of legislation designed to encourage public interest litigation, some Australian lawyers cling to the indemnity principle. ${ }^{57}$ Thinking freshly about costs is difficult for lawyers trained in the Australian legal tradition. Yet it may be vital if one goal of the law is to encourage litigants to come forward to uphold important constitutional and legal principles. The risks and dangers of an over-rigid approach to cost rules in constitutional litigation have been well described by Professor Patrick Keyzer. ${ }^{58}$

Innovative procedural rules and approaches to costs beyond the indemnity rule and pure discretion can sometimes contribute to vindicating presently unmet legal entitlements. At least a little time in a modern law course should be devoted to the irksome necessities of costs and their importance for the vindication of legal rights. Likewise the importance of the procedural rules governing orders for security for costs. The present costs rules can sometimes constitute a bridge too far for serious and justifiable public interest litigation. The law of standing to sue can also be another impediment. So may be the reluctance to admit an amicus curiae who might help decision-makers reach just and lawful outcomes. ${ }^{59}$

At the very least, more law teachers should familiarise themselves with the realities of the procedural and costs obstacles that exist on the journey towards vindicating legal rights presently unmet in our system

$57 \quad$ See, for example, the different opinions expressed in Oshlack v Richmond River Council [1998] HCA 11; 193 CLR 72.

58 Patrick Keyzer, 'A Battle and a Gamble: the Spectre of an Adverse Costs Order in Constitutional Litigation' (2011) 22(3) Bond Law Review 82; Iain Field, 'A Comment on Costs in Constitutional Cases' (2010) 22(3) Bond Law Review 104; Stephen Lloyd, 'Observations on Anecdata About Costs in Australian Constitutional Cases' (2011) 22(3) Bond Law Review 94.

59 Levy v Victoria (1997) 189 CLR 579, 600, 650; Wurridjal v Commonwealth [2009] HCA 2; 237 CLR 309, 312, 313 (procedural ruling) (per Kirby J (Crennan J concurring)). 
of law and justice. Any law course that omits consideration of costs and related procedural questions is akin to undertaking a performance of Hamlet without the Prince.

\section{G Enhance Technology for Access to Law}

Jeremy Bentham was the 'great questioner of all things established' ${ }^{60} \mathrm{He}$ was a proponent of codification of the law, in part because he thought it would promote greater simplification, rationality and accessibility in the law for those chiefly affected by it. He criticised 'Judge \& Co' (that is, the Bench and Bar of England), for what he saw as their 'sinister interest' in profiting from the unnecessarily complex and chaotic legal system under which it was often impossible for a litigant to discover reliably and in advance what his legal rights and duties were.

Great strides have been made in recent years to facilitate access to the letter of the law. Great credit for this must be given to three outstanding Australian academic lawyers, Graham Greenleaf (UNSW), Andrew Mowbray (UTS) and Philip Chung (UNSW). The establishment under their direction of AustLII (the free internet provision of basic legal data) was quickly followed by similar online services that provide effectively free access to legal information in a growing number of mainly Englishspeaking jurisdictions around the world. This has revolutionised the accessibility of the law. It aids judges, practising lawyers, law teachers and students. But it also has the potential to assist and support members of the public in finding access to basic legal principles and the binding rules of law, statutory and otherwise, that affect them.

One of the reasons why The Laws of Australia (published by Thomson Reuters) was written in a discursive style was to enhance the ability of lawyers who may have to start from scratch without any expertise in a particular area of the law. However, this legal encyclopaedia also reaches out to law students and also lay members of the public, potentially to help them find their way through the forest of the law. Because of the presently unmet needs for legal assistance and advice, these facilities become of even greater importance in helping self-represented litigants. Without legal training, they may simply clutch at straws. Often they try to resolve an incapacity for analysis by undiscriminating photocopying.

In principle, properly written legal texts and legal encyclopaedias, now accessible online, should have a capability to enhance general access to law and justice by the citizens. It is hard to imagine that the intricacies of Australian tax law could ever be reduced to easily accessible formulas. However, the drafting of statutes, the writing of judicial opinions and the creation of legal texts should accept, as their challenge, the now available marriage of legal information and the internet.

60 John Stuart Mill so described him; See Herbert Lionel Adolphus Hart's biographical note on 'Bentham' in AW Brian Simpson (ed), Biographical Dictionary of the Common Law (Butterworths, 1984) 44, 64, 46. 
Law students and newly qualified lawyers, at the beginning of their careers, will often be in a position similar to that of lay citizens with a legal problem but without relevant legal knowledge. Because current and future generations will grow up with developed digital capabilities, contemporary law teachers should accept Bentham's ideal. They should include interested lay citizens in their potential audience. So far as possible, they should write with the inexpert lawyer and law students in mind. But also an intelligent citizen who is governed by the law and therefore has a moral right to know what it is.

Judges and scholars who expound the law thereby influence the content of the law by their writing. They need to write more simply. Conceptualising law helps lawyers to write easily and simply. This was something I learned during my work in law reform, and not at law school. Some lawyers never learn this skill. Law teachers are bound to expound the law with constant references to judicial reasoning. In doing so they must mediate judicial language which is often obscure, either because of the uncertain state of the law but more often because of the complexity of much judicial writing. Learning the skills of expressing the law simply can be taught at law schools. Many basic rules are reasonably uncomplicated - short sentences; no passive voice; use of direct speech; and writing as we speak: with Germanic rather than Norman French words. ${ }^{61}$

\section{$\mathrm{H}$ Establish Clinics and Miscarriage Projects}

The discovery by any judge or lawyer that he or she may have played a part in a miscarriage of justice is an unsettling experience. If it results in an unjust judicial order, it is never forgotten. I was one of the Justices of the High Court of Australia who participated in the first application by the prisoner Andrew Mallard in Mallard $v$ The Queen. ${ }^{62}$ In 1997 he unsuccessfully sought special leave to appeal against his conviction of murder in the Supreme Court of Western Australia. A decade later, when a fresh application was made and granted, I participated in the appeal that set aside his original conviction. The hearing of his appeal strongly suggested (as was subsequently established by a judicial inquiry) that Mr Mallard was actually innocent of the crime. He had suffered a grave miscarriage of justice.

Unfortunately, there are more than a few such cases in Australia. Some mistakes are inherent in any human system of justice. However, the risk of error is exacerbated by the pressures imposed on courts of criminal appeal, where panels of judges have to handle large numbers of cases, so that mistakes are overlooked. Out of recognition of the defects of the local Criminal Appeal Act (copied from an Imperial template enacted in

61 Michael Kirby, Book Review (2006) 80 Australian Law Journal 623, Joseph Kimble, Lifting the Fog of Legalese - Essays on Plain Language (Carolina Academic Press, 2006).

62 [2005] HCA 68; 224 CLR 125. The refusal of special leave in the first application is noted (1997) 191 CLR 646. 
1907) moves have recently been taken for reform of the local law. In the United Kingdom, an independent commission has been created, with the resources, time and expertise to re-examine suspect cases.

In South Australia, as a result of the unflagging work of two admirable law teachers (Bibi Sangha and Robert Moles, Flinders), a facility to allow the reopening of decided appeals in some instances ${ }^{63}$ has been enacted by the State Parliament. Similar provisions have been proposed elsewhere, notably in Tasmania. The energy and determination of these two scholars represents a powerful vindication of the special obligation owed by scholars, who enjoy the protection of tenure, to investigate, analyse, understand and advocate the need for legal reform to help prevent or cure injustices. ${ }^{64}$ Yet the course of law reform is often slow. Meantime, from their cells, prisoners write to all and sundry asserting their innocence and offering arguments that, at least sometimes, appear to deserve a careful investigation that is not presently forthcoming.

The only avenue of redress available in most Australian jurisdictions for an alleged miscarriage of justice, once the application process has run its full course, is an application to the Executive Government under statute or for the exercise of the royal prerogative of mercy. In default of an independent, transparent legislative or judicial remedy, the creation of a university student-led 'innocence project' could sometime help establish a case of arguable innocence. Some critics dismiss this idea because of the lack of professional experience and judgment on the part of the students. On the other hand, beggars cannot be choosers. Law students in Australia are amongst the highest achievers in terms of university admission standards. Typically, they can bring great intelligence, motivation and time to bear on problems that may have been neglected for too long. I support the initiation of such projects. Apart from anything else, they would teach law students the central importance of detail; the high significance of facts and evidence for contested legal questions; and the serious risks of error that can sometimes arise in the law.

For similar reasons, I believe that law schools should be engaged with community legal services. Such links have already been established. Some (such as that between UNSW and the Kingsford Legal Centre) are intensive, substantial and of longstanding. They introduce law students to the privilege of being entrusted with the confidences and legal concerns of their fellow citizens. Recent changes in formal legal aid introduce new needs for flexibility and adaptability. Cuts in legal funding may reduce the facilities available for such centres and the opportunities for supervised student involvement. Ill-considered governmental prohibitions on advocating law reform based on the work of community centres should

63 Criminal Law Consolidation Act 1935 (SA) as amended from 5 May 2013. See Bibi Sangha and Robert Moles, Miscarriages of Justice: Criminal Appeals and the Rule of Law (LexisNexis, 2015) 104 [3.7.3].

64 Cf David Yamada cited in Nigel Stobbs 'Academic Freedom and University Autonomy' in Sally Varnham, Patty Kamvounias and Joan Squelch (eds), Higher Education and the Law (Federation Press, 2015) 214. 
be reconsidered. Partisan political engagement and criticisms must occur outside publicly funded institutions. But drawing lessons for reform of the law is a lifelong obligation of lawyers. It is a lesson and habit that should be taught in all law schools. Community legal centres, innocence projects and civil society institutions are all places where law students should be encouraged to get involved and stay involved.

\section{Engage in Empirical Research and Law Reform}

My experience between 1975-1984 in the Australian Law Reform Commission taught me the vital importance of empirical research concerning the operation of the law. In the ALRC's report on Criminal Investigation, the researchers travelled with the police and accused in police vans. They watched the process of investigation close up, in order to scrutinise what the law was, and what it should be. ${ }^{65}$ In the project on debt recovery, ${ }^{66}$ the research included engagement with volunteer counsellors at Lifeline and other helping organisations as they counselled people who had become out of their depth in borrowing. The project on tissue transplantation involved contact with potential donors and their families as well as with recipients and their organisations. ${ }^{67}$

The time has long passed when lawyers could wash their hands of responsibility for the state of the law. Or could consider that the solution to problems was to be found solely in judicial opinions rather than real life experiences. Law teachers have long taken a leading role in institutional law reform. The first full-time commissioner of the ALRC (after myself) was a gifted scholar and law teacher recruited from the University of Adelaide, Professor David St L Kelly. His work on insurance law reform, ${ }^{68}$ in particular, was an outstanding achievement. Based on empirical studies of consumer expectations and close consultation about industry needs, it produced a national law that greatly simplified the applicable rules. It was a stunning success. ${ }^{69}$

Institutional law reform has also suffered severe recent funding cutbacks. This has led to a reversion, in some Australian jurisdictions, to the part-time model of law reform which the Scarman model in England of 1965 had aimed to replace. More law teachers should promote, amongst their students and in the community, the need for more, not less, long term, empirically-based, institutional reform of the law. Essentially, this is an obligation of good governance. To the extent that the law and its

65 Australian Law Reform Commission, Criminal Investigation, Report No 2 (1975).

66 Australian Law Reform Commission, Insolvency: The Regular Repayment of Debts, Report No 6 (1976).

67 Australian Law Reform Commission, Human Tissue Transplants, Report No 7 (1977).

68 Australian Law Reform Commission, Insurance, Agents and Brokers, Report No 16 (1980); Australian Law Reform Commission, Insurance Contracts, Report No 20 (1982).

69 Michael Kirby, 'Insurance Contract Law Reform - 30 Years On' (2014) 26 Insurance Law Journal, 1. 
machinery becomes out of date; unjust and inefficient, they fall prone to corrupt practices, unjust outcomes and civic disillusionment.

One of the many reasons why Australia needs to adopt legislation enshrining universal rights is so that legal process, affording access to the courts, will identify any serious departures from basic legal principles, including the principle of equal justice for all. Court decisions may lead to beneficial parliamentary attention to law reform. An attitude that scrutinises critically the state of the law is appropriate. It should be encouraged from the earliest days in law school. In my legal classes no-one ever raised a question concerning the injustice of the treatment of Aboriginals in the Australian legal system. No one ever questioned the White Australia Policy or asked the students to consider whether it was just or wise or conformable to the then newly adopted Universal Declaration of Human Rights 1948. No one questioned the injustice, and patriarchal content, of much of the law then affecting women, such as the law of coverture and domicile. $^{70}$ No one questioned the laws against homosexuals. I can say this with certainty because I would certainly have remembered if anyone had done so. ${ }^{71}$

Australian lawyers were very complacent, unquestioning and, uncritical at that time. Law teachers (at least outside the Department of Jurisprudence and International Law at Sydney University, led by Professor Julius Stone) rarely raised basic issues of justice and universal rights. It was enough, we were told, to learn the law by heart. That attitude fitted comfortably with the views of most members of the judiciary and the legal academy at the time. It matched the profile of most of the intake into the six law schools that then operated in Australia. However, a lawyer learns the law better by considering its operation and any defects that appear to argue for reform. Law teachers should be alert to that ongoing obligation. They should inculcate it in their students. In the $1950 \mathrm{~s}$, we were unquestioning and passive. Some never threw off that habit of mind. A few were even proud of their indifference to the substance of what they did as lawyers. Such attitudes should disappear from our legal culture. The place to start is in legal education.

\section{J Consider Lessons From Foreign Systems}

Most of the countries of the world follow the civilian tradition of the law, copied substantially from the Napoleonic Codes of France. In many ways, it is a more efficient system for resolving legal disputes. It tends to build into the functions of judges and magistrates a more active engagement

70 See, for example, Australian Law Reform Commission, Equality Before the Law: Women's Access to the Legal System, Report No 67 (1994); Australian Law Reform Commission, Equality Before the Law: Justice for Women: Part I, Report No 69 (1994).

71 Crimes Act 1900 (NSW) ss 79-81B provided the relevant criminal offences at the time. There were equivalent provisions in the Criminal Code Act 1995 (Cth) and the criminal legislation of every Australian jurisdiction. 
with, and responsibility for, the gathering of evidence. The common law system may be more transparent in its procedures. But with its emphasis on adversarial litigation and the accusatory procedure in criminal trials, it is generally slower and more expensive.

This point was made in Australia in 1981 by a visiting German judge. He declared that the German legal system could not really compare to the Australian. It was a Volkswagen compared to a Rolls Royce. But how many, he asked, could afford a Rolls Royce ${ }^{72}$

Since the Court of Star Chamber, English speaking people tend to be suspicious of the European inquisitorial model. They point to the necessity that an investigating judge must ordinarily formulate a 'theory of the case' in order to conduct the investigation. Such pre-conception might risk prejudgment, leading to expected (desired) outcomes. The adversarial and accusatory systems, on the other hand, are inherently dependent on a number of elements: skilled legal representation; equality of legal arms; and rough equality of professional talent and experience. Amongst people who are involved in a legal dispute, those who cannot afford a lawyer or who are represented by an inexperienced or incompetent lawyer, may never attain justice according to law.

There is some evidence that (encouraged by the entry into the European Union of the United Kingdom and other common law European jurisdictions) the two global legal traditions derived from Europe may be moving together. Each may be adapting features of the other. Judicial officers of our system, faced by increasing numbers of self-represented litigants, must sometimes feel that they are operating a hybrid variety of the European model. A lay tribunal, without much professional legal assistance, may do likewise. The very risks of lengthy trials, contentious appeals, hugely costly proceedings and uncertain outcomes, with strictly confined participation by the actual parties, have produced a substantial trend towards mediation, arbitration, conciliation and other forms of alternative dispute resolution (ADR). Because these procedures typically occur in private behind closed doors and with little or no judicial participation or supervision, they constitute an alternative model to public litigation. That model has its own problems and defects.

However, the skills that ADR demands are different. After a thousand years, the continuous oral trial, transparently conducted before a public official called a judge, may, at last have almost priced itself out of its market. If cost were not the only consideration, the incorporation of mandatory ADR and 'investor-state dispute provisions' and treaty tribunals in free trade agreements mean that national constitutional decisions may now occasionally be bypassed or undermined. The parties may ultimately seek access not to national courts of law but to tribunals of the World Trade

$72 \quad$ Wolfgang Zeidler quoted in [1981] Reform 75; cf Wolfgang Zeidler, 'Evaluation of the Adversary System: As Comparison, Some Remarks on the Investigating System of Procedure' (1981) 55 Australian Law Journal, 390; see also Kirby, above n 19,34 . 
Organisation and Investor - State Dispute Settlement bodies (ISDS) essentially created to defend business interests and economic objectives. ${ }^{73}$

When the decisions and orders of the High Court of Australia, pronounced in contested litigation under the Constitution, upset investors in the tobacco industry such a body was established. Proceedings before it were ultimately dismissed. However, when a nation's independent and final constitutional court can effectively be rendered subject to an offshore body of private lawyers sitting in foreign countries, created pursuant to a trade treaty, it is clear that the law is in a state of significant change. The fundamentals that have been respected, indeed unquestioned, for a century and more - including for the entire life of the nation-are opened to serious doubt..$^{74}$

The need for outstanding law teachers, capable of addressing such fundamental questions, has never been greater. Significant national and international business interests will continue to call on lawyers of the greatest ability. It is equally important that lawyers of talent and imagination should be available to other interests in society. Such interests include those of national constitutionalism; electoral democracy; the proper role of final courts; and the other human rights interests of all citizens.

\section{K Attaining Balance}

It was unsurprising that WS Gilbert and Sir Arthur Sullivan should have addressed many times the faults and foibles of the law. WS Gilbert was, after all, a barrister. His brilliant lyrics are a tribute to his training at the Bar.

In Mikado, he portrayed the Lord High Executioner. In Iolanthe, he parodied the Lord Chancellor. In Trial by Jury, he cut close to the bone of jury trial. But it is his gavotte in The Gondoliers that helps to make my final point. The words in question have nothing specific to do with the law; still less with legal education. However, they address an issue that is very English. It is relevant to the legal system that the English introduced to the common law world, including Australia. The words appeal to the maintenance of a balance in all things. The avoidance of extremes. The rejection of rigidity and self-satisfied immobility. The search for the mean. The words should not only be written. They should be sung. The Duke of Plaza Toro gives advice to his two charges, Marco and Giuseppe, as to

73 Jo Delaney, 'ISDS: The risks and rewards' Lawyers Weekly (online), 27 July $2015<$ http://www.lawyersweekly.com.au/opinion/16878-isds-therisks-and-rewards\#disqus_thread>.

74 This is a reference to the invocation of a treaty tribunal challenging the finality of the determination of the High Court of Australia in JT International SA $v$ Commonwealth (2012) 250 CLR 1; [2012] HCA 43. That decision (Heydon J dissenting) rejected an attack on the constitutional validity of the Tobacco Plain Packaging Act 2011 (Cth). It led to the resort of cigarette producing companies to the treaty mechanism to claim damages for losses from denial of their intellectual property in cigarette brand names. The claim was dismissed. 
how to dance a gavotte. They were instructed to display a perfect aristocratic balance: pitched equally between too much stiffness and excessive informality: ${ }^{75}$

Duke: That's if anything, too unbending -

Too aggressively stiff and grand.

(They suddenly modify their attitudes)

Now to the other extreme you're tending -Don't be so deucedly condescending! ...

Marco \& Giuseppe: Oh, hard to please some noblemen seem!

At first if anything too unbending;

Off we go to the other extreme-

Too confoundedly condescending!

This, I suggest, is the challenge that faces law teachers in Australia engaged in a kind of intellectual gavotte. To be aware of the faults and dangers of their subject. To praise its strengths and its achievements. But in doing so, to avoid unbending stiffness or uncritical pride. And in correcting its faults, retaining an appropriate measure of formality but avoiding the perils of over familiarity, indifference and condescension.

I have endeavoured to walk that median path. I have acknowledged and praised the features of our legal system deserving of praise. But I have suggested some fundamental flaws and faults that leave too many of our citizens with theoretical legal entitlements that can never actually be attained.

It is to address those unmet needs for legal services that I have proffered my new ten commandments. I can only hope that they will be learned by the teachers and lawyers of tomorrow. If they learn well, and practise what they have learned, they will leave the law in a state better than they found it. And that should be every lawyer's ambition and duty. 